\title{
CORRELATION OF THE UNDERSTANDING ENVIRONMENT CONCEPT WITH THE CHARACTER ENVIRONMENT CARE FOR THE BIOLOGICAL EDUCATION STUDENTS
}

\author{
Sirtu Filaili Sari, Jamaluddin*, and Mahrus \\ Biology Education Study Program, Faculty of Teacher Training and Education, University of Mataram, \\ Indonesia \\ *Email: Jamalbio2017@gmail.com
}

\author{
Accepted: January 02, 2022. Approved: January 14, 2022. Published: January 21, 2022
}

\begin{abstract}
This study aims to determine the relationship between understanding the concept of the environment and the character of caring for the environment for students of the Biology Education S1 study program. This type of research is descriptive quantitative. The research was conducted online via google Forms on biology education students who have passed environmental courses. The results showed that the correlation value between the understanding of environmental concepts and the student's environmental care character (r) was 0.601 , and the coefficient of determination ( $\mathrm{r} 2$ ) was 0.3612 , so it can be stated that there is a positive and significant relationship. In conclusion, there is a meaningful positive relationship between understanding the concept of the environment and the value of caring for the environment in students of the Bachelor of Biology Study Program. The contribution of environmental understanding to the character of caring for the environment is $36.12 \%$, and the remaining $63.88 \%$ is outside the understanding of environmental concepts.
\end{abstract}

\section{Keywords: Correlation, Understanding Environment Concept, Character Environment Care, Biological} Education Students

\section{INTRODUCTION}

Environmental knowledge is one of the compulsory subjects in the Biology Education Study Program, which studies the relationship between living things and their environment, the classification of the environment is divided into two categories, namely the biotic and abiotic environment [1]. The abiotic component includes all inanimate objects on the earth's surface. Examples of the biotic environment include soil, water, air, humidity, acidity $(\mathrm{pH})$, and sunlight. The biotic component contains all living things such as flora, fauna, and humans [2].

The environment is where all human activities will impact the environment, namely environmental changes. Realizing that humans are part of the environment, humans need to have good ethics to live with their environment. Therefore, humans need to be equipped with good environmental knowledge to maintain and preserve their habitat. Humans can improve the quality of positive attitudes and behavior towards the environment through ecological science.

Environmental knowledge has an important meaning for students, namely to know the fundamental sources of human life to analyze environmental problems and provide solutions. Through this Environmental Knowledge course, students need to understand the concept of the environment as one of the provisions to become a teacher.

Caring for the environment is an obligation for every human being. Many environmental problems in Indonesia have occurred because of wrong things done by humans such as littering, using environmentally unfriendly technology, overexploiting nature, and others, causing various kinds of pollution (water, air, and soil) to decrease environmental quality. Several phenomena that occur due to the declining quality of the environment cannot be separated from the behavior of human indifference to the environment. Other experts also explain that environmental problems are natural problems. However, environmental problems can no longer be purely natural because humans are a significant causal factor for environmental events [3].

These problems occur due to a lack of human awareness to protect the environment, so humans need to improve their environmental knowledge. One of the efforts that can be done is by applying ecological science students to care about the surrounding environment to overcome this problem. Students are expected to understand and care for the environment through ecological science. Other experts also explain that intensive environmental education will improve the quality of positive behavior towards the environment. Education can realize the mental readiness of students and has a desire to do positive things for the environment [4].

Environmental ethics is very important to implement in human life because ecological problems and natural disasters are basically caused by a wrong understanding that nature is an object that can be exploited as we wish [5]. This kind of understanding needs to be changed because the damage happening in the present is not only felt by us today but will also be felt by generations to come. Environmental care described in the character education component is related to the ecological material studied by Biology Education 
undergraduate students. This environmental course requires students to understand the concept of the environment as one of the provisions to become teachers in teaching students in the future. Other experts also explained that education is one of the efforts to raise students' awareness to manage the environment in an environmentally responsible way [6]. Therefore, the study is needed to determine the correlation of the understanding environment concept with the character environment care for the biological education students.

\section{RESEARCH METHOD}

This research used the descriptive method. This type of research is descriptive quantitative research, describing the relationship between understanding environmental concepts (X) and environmental care character $(\mathrm{Y})$ in Biology Education students. The population in this study were all students of Biology Education FKIP University of Mataram. The sampling technique used was purposive sampling, specifically specific reasons for taking the sample [7]. From a population of 490 students, 120 students were used as samples because students had passed environmental science courses.

The data collection used a test instrument for understanding environmental concepts and a character questionnaire that cares for the environment. The research implementation technique is done online via a google form. The data were analyzed using product moment with the help of SPSS 17 to test the truth of the hypothesis in this study.

\section{RESULTS AND DISCUSSION}

Understanding the concept of the environment and the character of environmental care for students can be seen through the profile of student character education depicted in table 1 and table 2. Table 1 shows that the profile of conceptual understanding in terms of indicator achievement shows that three indicators are not achieved, namely, indicator 1) explains the understanding of the environment with cognitive dimensions (C2). The indicator was not achieved because item 1 had answer options that deceived the participants. In determining the answers, many students seemed to be fooled by the answer options provided, so that out of 120 students, only 28 students could answer item 1 correctly. Meanwhile, the non-achievement of indicators 4 and 8 are included in the cognitive dimension C4 (analyzing) level, which requires students to have HOTS skills (Higher Order Thinking Skills). Based on this, students' analytical skills are still considered lacking in indicators 4 and 8 because they have not been able to analyze and determine solutions to environmental damage based on existing facts.
Table 1. Profile of achievement indicators for student understanding environmental concepts

\begin{tabular}{lr}
\hline $\begin{array}{l}\text { Environmental Care } \\
\text { Questionnaire Indicator }\end{array}$ & $\begin{array}{c}\text { Achievement } \\
\text { Percentage }\end{array}$ \\
\hline $\begin{array}{l}\text { Cleanliness attitude and } \\
\text { responsibility }\end{array}$ & $76 \%$ \\
$\begin{array}{l}\text { Do not litter } \\
\text { Do not scratch trees, walls, } \\
\text { road stones, and others }\end{array}$ & $83 \%$ \\
Utilizing the type of waste & $95 \%$ \\
$\begin{array}{l}\text { Always throw trash in its place } \\
\text { Manage the surrounding } \\
\text { environment well }\end{array}$ & $62 \%$ \\
$\begin{array}{l}\text { Applying environmental theory } \\
\text { with an attitude of caring for } \\
\text { the environment }\end{array}$ & $79 \%$ \\
$\begin{array}{l}\text { Determine efforts and solutions } \\
\text { for environmental damage } \\
\text { Creating a clean environment }\end{array}$ & $72 \%$ \\
\hline
\end{tabular}

Table 2. Profile of Achievement of Character Education Questionnaire Indicators (Student Environmental Care)

\begin{tabular}{lr}
\hline $\begin{array}{l}\text { Environmental Knowledge Test } \\
\text { Indicator }\end{array}$ & $\begin{array}{l}\text { Achievement } \\
\text { Percentage }\end{array}$ \\
\hline $\begin{array}{l}\text { Explain the meaning of the } \\
\text { environment }\end{array}$ & $38 \%$ \\
$\begin{array}{l}\text { Explain environmental objectives } \\
\text { and environmental impact } \\
\text { analysis }\end{array}$ & $82 \%$ \\
$\begin{array}{l}\text { Explain the components of the } \\
\text { environment } \\
\text { analyzing the definition of } \\
\text { environmental problems }\end{array}$ & $69 \%$ \\
$\begin{array}{l}\text { Explain the value and benefits of } \\
\text { biodiversity }\end{array}$ & $46 \%$ \\
$\begin{array}{l}\text { Analyzing prospects, efforts, and } \\
\text { strategies for biodiversity }\end{array}$ & $83 \%$ \\
sustainability for human well- \\
being \\
$\begin{array}{l}\text { Analyze the causes and impacts } \\
\text { of environmental damage } \\
\text { Determine solutions to } \\
\text { environmental damage }\end{array}$ & $67 \%$ \\
\hline
\end{tabular}

Students can not achieve the indicators with a cognitive level of C4 [8]. The students' achievement is dominant in the cognitive level indicators $\mathrm{C} 1, \mathrm{C} 2$, and $\mathrm{C} 6$. The indicator that gets the lowest percentage analyzes the problems that exist in the environment [9]. It is due to the lack of thoroughness of students reading the information contained in the test readings with the questions presented. The achievement indicators between 
students are also expected to the different initial knowledge each student obtains.

Table 2 shows that all indicators of the value of caring for the environment have been achieved, meaning that the understanding of character education regarding the value of caring for the environment is very good. Understanding character education is very important for students because they are prospective teachers who will teach something good that their students will emulate in the future. Therefore, becoming a teacher in the $21 \mathrm{st}$ century requires students to understand the character.

Character education is a habit, so forming one's character requires a community of character consisting of family, school, and various parties that influence the younger generation [10]. Character building also requires exemplary development, which is transmitted through a continuous learning, training, and habituation process in the long term. Other experts also explain that character education determines how a person thinks and behaves. Good character can encourage one to do good, approve someone who does good, or have a noble character [11].

Planting an attitude of caring for the environment can be done through habituation or habituation [11]. One of the means to get used to caring for the environment is through environmental education. Environmental education is a means that can change human perceptions, attitudes, and behavior to care about their environment.

Understanding environmental concepts and the character of students' ecological care can also be seen through the overall score results and the score results in each class in terms of the average value depicted in Figures 3 and 4.

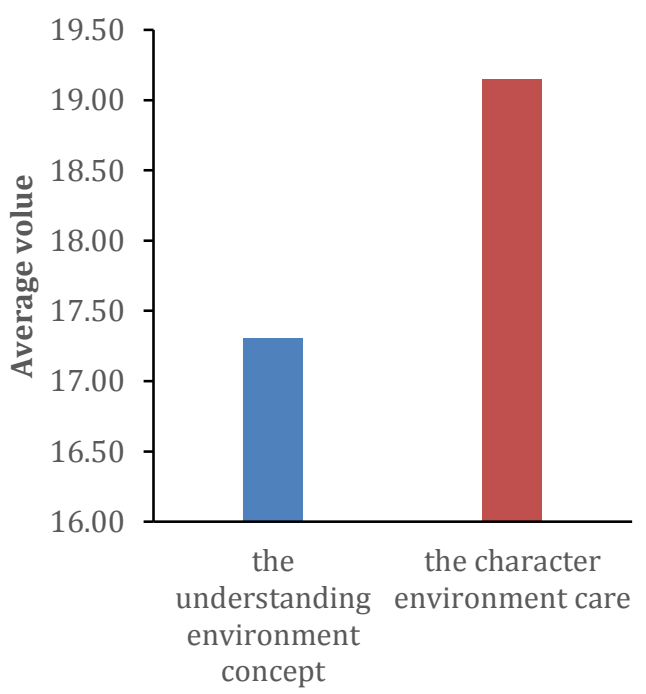

Figure 1 Average Understanding Environmental Concepts and Students' Character Environmental Care
Figure 1 shows that the understanding of environmental concepts and the character of environmental care for students is in the medium category with an overall average value of understanding environmental concepts of 17.31 and environmental care character of 19.15 . Understanding the concept of the environment in prospective biology education teachers is very important. Considering the task of prospective teachers must master the concept of material before being taught to their students in the future where environmental concepts are compulsory subjects studied by biology education students. Ecological education has been applied through learning biology. Therefore ecological education from students has an important role in maintaining and preserving the environment [13]. Students with high scores do not necessarily have a high environmental care attitude [14]. Other factors that also influence the change in attitudes include internal factors in personal experience, background, and motivation and external factors in social influences, culture, and information received by individuals.

Figure 2 shows that understanding environmental concepts and environmental care characters in biology education students have different scores in each class. The difference in the results of scores on student character education can be influenced by various factors in each student, including home environmental factors, campus environments, and others. The formation of a person's character is influenced by many factors such as the living environment, campus environment, academic atmosphere that supports student character development [15].

The results of the correlation analysis between the understanding of environmental concepts and the environmental care character of Biology Education undergraduate students using the product-moment with the help of SPSS 17 are shown in Table 3.

Table 3 shows that the correlation value between understanding the concept of the environment (variable $\mathrm{X}$ ) and the character of caring for the environment (variable Y) is obtained. The correlation value "r" is 0.60."r" value Pearson Product Moment shows a strong correlation because it is located between $0.60-0.799$ [16]. It means that there is a strong relationship between understanding the concept of the environment and caring for the environment.

$r$ value calculated obtained is 0.60 and then compared with the $r$ table value for an error level of $5 \%$ with $\mathrm{n}=120$, it is known that the $\mathrm{r}$ table is 0.179 . Because the value of $r$ arithmetic is more significant than $r$ table for an error level of 5\% (0.60>0.179), the correlation between the two variables is declared positive and effective. Ho is rejected, and $\mathrm{Ha}$ is accepted. Thus, it can be concluded that there is a positive and significant relationship between 
understanding the concept of the environment and the environmental care character of Biology education students. The student's understanding of the ecological concept influences the education of the environmental care character.

The formation of a person's attitudes and behavior comes from knowledge. High knowledge about the environment will make it easier for students to apply a caring attitude towards the environment. Humans and nature have a mutually beneficial and detrimental relationship [17-19]. The abilities of humans and nature largely determine the

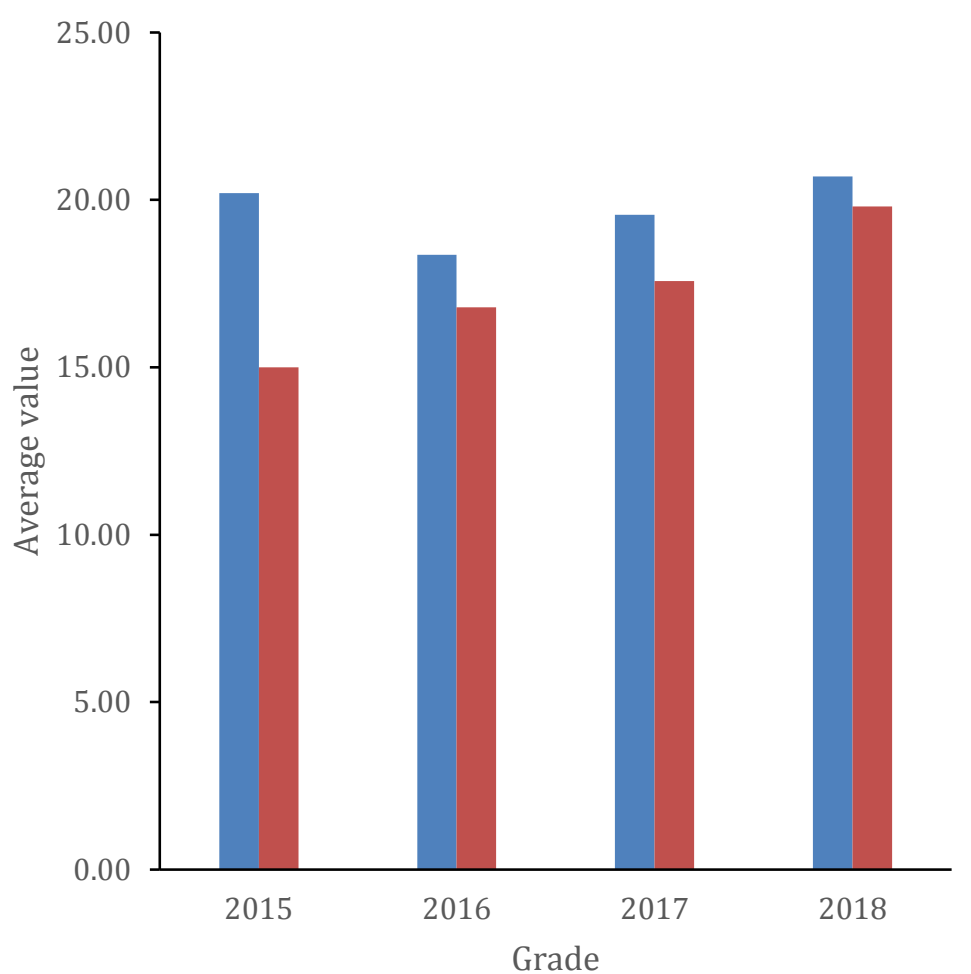

Figure 2. Average Scores of Environmentally Concerned Character Education and Understanding of Environmental Concepts Students in each class

Table 3. The results of the Pearson product-moment correlation analysis (SPSS 17)

\begin{tabular}{|c|c|c|c|c|}
\hline \multicolumn{2}{|c|}{ Correlation } & \multirow{2}{*}{$\begin{array}{l}\text { Character Caring for } \\
\text { the Environment } \\
1.601\end{array}$} & $\begin{array}{c}\text { Understanding } \\
\text { Environmental } \\
\text { Concepts }\end{array}$ & \multirow{3}{*}{$\begin{array}{c}\text { Level of } \\
\text { Relationship } \\
\\
\text { Strong }\end{array}$} \\
\hline Understanding & Pearson Correlation & & $* *$ & \\
\hline Environmental & & & & \\
\hline Concepts & Sig. (2-tailed) & & .000 & \\
\hline & $\mathrm{N}$ & 120 & 120 & \multirow{4}{*}{ Strong } \\
\hline \multirow{3}{*}{$\begin{array}{l}\text { Environmental Care } \\
\text { Characters }\end{array}$} & Pearson Correlation & $.601 * *$ & 1 & \\
\hline & Sig. (2-tailed) & .000 & & \\
\hline & $\mathrm{N}$ & 120 & 120 & \\
\hline
\end{tabular}

reciprocal relationship between humans and nature according to their respective characters.

Furthermore, the coefficient of determination is tested, namely the square of the correlation coefficient $\left(\mathrm{r}^{2}\right)$, to determine the contribution of variable $\mathrm{X}$ to variable $\mathrm{Y}$. The calculations obtained a value of $36.12 \%$. It shows that variable $\mathrm{X}$ (understanding of environmental concepts) contributes to variable $\mathrm{Y}$ (environmental care character) is $36.12 \%$. The remaining $63.88 \%$ is outside the knowledge of ecological concepts. ne character environment care

- the understanding environment concept 
This cheerful and significant relationship can be interpreted that the higher the students' environmental knowledge, the higher the students' ecological care attitude. The results of this study are similar to the effects of previous studies reported by several researchers who reported that the higher the environmental knowledge possessed by students, the higher the attitude of caring for the environment [20-22]. Based on the results of this study, the relationship between understanding the concept of the environment and the students' environmental care character is a type of reciprocal relationship. The reciprocal relationship is between one variable and another variable that can be a cause and an effect. In this connection, it can be determined that understanding environmental concepts is the cause of students' ecological care.

\section{CONCLUSION}

Based on the results of the research and discussion, it can be concluded that there is a positive and significant relationship between the understanding environment concept with the character environment care for the biological education students with a correlation value of $r_{\text {count }}$ $(0.60)>r_{\text {table }}(0.179)$. This relationship includes a reciprocal relationship, meaning that the higher the understanding of environmental concepts, the higher the student's environmental care character. On the other hand, the higher the student's environmental care character value, the higher the understanding of environmental concepts.

\section{REFERENCES}

[1] Taqiya, W. (2013). Pengaruh intensitas keikutsertaan siswa SMA/SMK/MA dalam satuan karya Pramuka (Saka) Wanabakti kabupaten Pekalongan terhadap kepedulian lingkungan hutan (Doctoral dissertation, IAIN Walisongo).

[2] Ilhamdi, M. L. (2012). Keanekaragaman Serangga Dalam Tanah Di Pantai Endok Lombok Barat. Jurnal Pijar Mipa, 7(2).

[3] Herlina, N. 2017. Permasalahan lingkungan hidup dan penegakan hukum lingkungan di Indonesia. Jurnal Ilmiah Galuh Justisi, 3(2), 162-176.

[4] Hasnidar, S. (2019). Pendidikan Estetika dan Karakter Peduli Lingkungan Sekolah. Jurnal Serambi Ilmu, 20(1), 97-119.

[5] Said, M. Y., \& Nurhayati, Y. (2020). Paradigma Filsafat Etika Lingkungan Dalam Menentukan Arah Politik Hukum Lingkungan. Al-Adl: Jurnal Hukum, 12(1), 39-60.

[6] Udhiyah, I., Sulaimi, M., \& Bidjaksono, D. (2019). Peningkatan Kemampuan Siswa Menerapkan Pemahaman Materi Pembelajaran Dan Sikap Peduli Lingkungan Melalui Metode Pembelajaran
Kooperatif Tipe Numbered Heads Together (NHT) Berbantuan Media Video Pembelajaran Pada Mata Pelajaran PKn di Ma Al-Aziziyah Putri. Jurnal Pendidikan Sosial Keberagaman, 2019, 5.1.

[7] Setyosari, P. (2013). Metode Penelitian Pendidikan dan Pengembangan. Jakarta: Prenada Media Group.

[8] Aini, M. H. (2014). Penguasaan Konsep Lingkungan Dan Sikap Peduli Lingkungan Siswa Sma Adiwiyata Mandiri Di Kabupaten Mojokerto. Berkala Ilmiah Pendidikan Biologi (BioEdu), 3(3).

[9] Susanti, D. Y. (2017). Keefektifan Lks Vermikomposting untuk Melatihkan Keterampilan Proses Sains Pada materi Perubahan Lingkungan dan Daur Ulang Limbah Kelas X. Berkala Ilmiah Pendidikan Biologi (BioEdu), 6(3).

[10] Komara, E. (2018). Penguatan pendidikan karakter dan pembelajaran abad 21. Sipatahoenan, 4(1).

[11] Supriadi., Wildan., \& Laksmiwati, D. (2020). Implementasi Model Pembelajaran Berbasis Masalah dan Pengaruhnya Terhadap Perkembangan Karakter Mahasiswa. Jurnal Penelitian Pendidikan IPA (JPPIPA). 6(1). pp. 63-68.

[12] Pratama, D. N., Karyanto, P., \& Ariyanto, J. (2018). Pengembangan Subject Spesific Pedagogy Berbasis Problem Based Learning Untuk Penguatan Sikap Peduli Lingkungan. Jurnal Penelitian Pendidikan, 21(1).

[13] Nisa, N. A., Surbakti, A., \& Yolida, B. (2018). Hubungan antara Pengetahuan tentang Ekosistem dengan Sikap Peduli Lingkungan. Pendidikan Biologi: Universitas Lampung.

[14] Widyastuti, Y. (2014). Psikologi Sosial.Yogyakarta: Graha Ilmu.

[15] Dhiu, K. D., \& Bate, N. (2018). Pentingnya Pendidikan Karakter Di Perguruan Tinggi: Kajian Teoritis Praktis. Jurnal Ilmiah Pendidikan Citra Bakti, 172-176.

[16] Sugiono. (2013). Metode Penelitian Kuantitatif Kualitatif Dan R\&D. Bandung: Alfabeta.

[17] Cahyani, A. K. (2013). Hubungan Timbal Balik Antara Manusia Dengan Lingkungan Di Tama New Town Yang Tercermin Dalam Anime Heisei Tanuki Gassen "Pompoko" Karya Takahata Isao. Jurnal Ilmiah Mahasiswa FIB, 1(7).

[18] Armiani, S., \& Harisanti, B. M. (2021). Hubungan Kemelimpahan Fitoplankton dengan Faktor Lingkungan di Perairan Pantai Desa Madayin Lombok Timur. Jurnal Pijar Mipa, 16(1), 75-80.

[19] Bowen, S. A. (2020). Intelligences in Strategic Issues Management: Challenging the Mutually 
Beneficial Relationships

Paradigm. Partecipazione e conflitto, 13(2), 1002-1021.

[20] Azhar, A., Basyir, M. D., \& Alfitri, A. (2015). Hubungan pengetahuan dan etika lingkungan dengan sikap dan perilaku menjaga kelestarian lingkungan. Jurnal Ilmu Lingkungan, 13(1), 3641 .

[21] Ahmadi, R., Surbakti, A., \& Jalmo, T. (2018). Hubungan Pengetahuan Lingkungan Hidup dengan Sikap Peduli Lingkungan Hidup. Jurnal Bioterdidik Wahana Ekspresi Ilmiah, 6(2).

[22] Bunga, N. I. (2020). Hubungan Pengetahuan Dan Etika Lingkungan Terhadap Perilaku Peduli Lingkungan Mahasiswa Universitas Kristen Tentena. 